\title{
Spatial structure and ecological variation of meroplankton on the Belgian-Dutch coast of the North Sea
}

\author{
A. Belgrano $^{1, *}$, P. Legendre ${ }^{2}$, J.-M. Dewarumez ${ }^{1}$, S. Frontier ${ }^{1}$ \\ ${ }^{1}$ Université des Sciences et Technologies de Lille, Station Marine (URA CNRS 1363), BP 80, F-62930 Wimereux, France \\ ${ }^{2}$ Département de sciences biologiques, Université de Montréal, CP 6128, Succursale A, Montréal, Québec, Canada H3C 3J7
}

\begin{abstract}
Spatial structure and the spatial autocorrelation of meroplankton compositional patterns were investigated by canonical correspondence analysis (CCA) and complementary Mantel statistics to contribute to the understanding of the complex biological fluxes in the coastal waters between the Belgian coast and the Scheldt estuary region. The use of covariables in a partial ordination method allows the partitioning of environmental and spatial variation in order to test meroplankton successional patterns. The direction and intensity of wind was responsible for a northeasterly transport of larvae. Reverse wind conditions allowed for a southwesterly larval dispersal. The spatial pattern of the species comes from the spatial pattern of the environmental variables, and is completely explained by them, so that no significant spatial pattern remains in the species data after controlling for the effect of the environmental variables. The spatial structure therefore can be regarded as an explanatory variable in ecological studies.
\end{abstract}

KEY WORDS: North Sea - Meroplankton - Spatial heterogeneity · Canonical correspondence analysis (CCA) Constrained ordination - Mantel statistics - Environmental control model

\section{INTRODUCTION}

The aim of this study was to quantify the spatial heterogeneity of the meroplankton community structure in a coastal location situated within an estuarine system, and to identify the factors responsible for it. Studying spatial structure in ecosystems is important for understanding ecological stability (May 1984), and should be considered in ecological research programs (Legendre et al. 1989). The development of new statistical methods (ter Braak 1987, 1988b, Borcard et al. 1992) allows detailed study of the spatial structuring of the environment related to biological processes and further understanding of community-based spatial processes. The hydrodynamic regime of the Southern Bight of the North Sea is characterized by strong

\footnotetext{
·E-mail: andrea@loalit.univ-littoral.fr
}

mesoscale currents produced by tides and winds, concomitant with residual currents generated by the flow through the North Sea of the 2 branches of the North Atlantic current (Nihoul 1975, 1980, Nihoul \& Runfala 1981, Nihoul \& Ronday 1975), and by the presence of a residual gyre along the Belgian coastal zone off Zeebrugge. The Westerschelde estuary ebb-tide channel, running parallel to the northern Belgian coast reaching Oostende, and the flood-tide channel running parallel to the Dutch coast at Vlissingen are responsible for the dilution of the Westerschelde estuary waters with the open sea (Nihoul et al. 1989). The Oosterschelde estuary is characterized by strong tidal currents and can be regarded as a well-mixed zone (Dronkers \& Zimmerman 1982). The closure of 2 storm surge barriers in 1986 and 1987 (Wetsteyn et al. 1990) resulted in the reduction of the amount of water exchange with the North Sea by approximately $28 \%$ (Leewis \& Waardenburg 1990). 


\section{METHODS}

Data. The sampling campaigns were conducted on 5 and 11 June 1990 along a transect from Zeebrugge (Belgium) to the eastern Scheldt estuary (The Netherlands), 40 nautical miles into the Southern Bight of the North Sea (Fig. 1), in connection with the research program RENORA founded by the PNDR (Programme National sur le Déterminisme du Recrutement, France). The NOAA-AVHRR satellite images for the period of the RENORA campaign (May to June 1990) and the wind direction and velocity were obtained from KNMI (Royal Netherlands Meteorological Institute). Fluorometry, temperature, salinity and water density were measured at $20 \mathrm{~s}$ intervals by a hydrological probe.
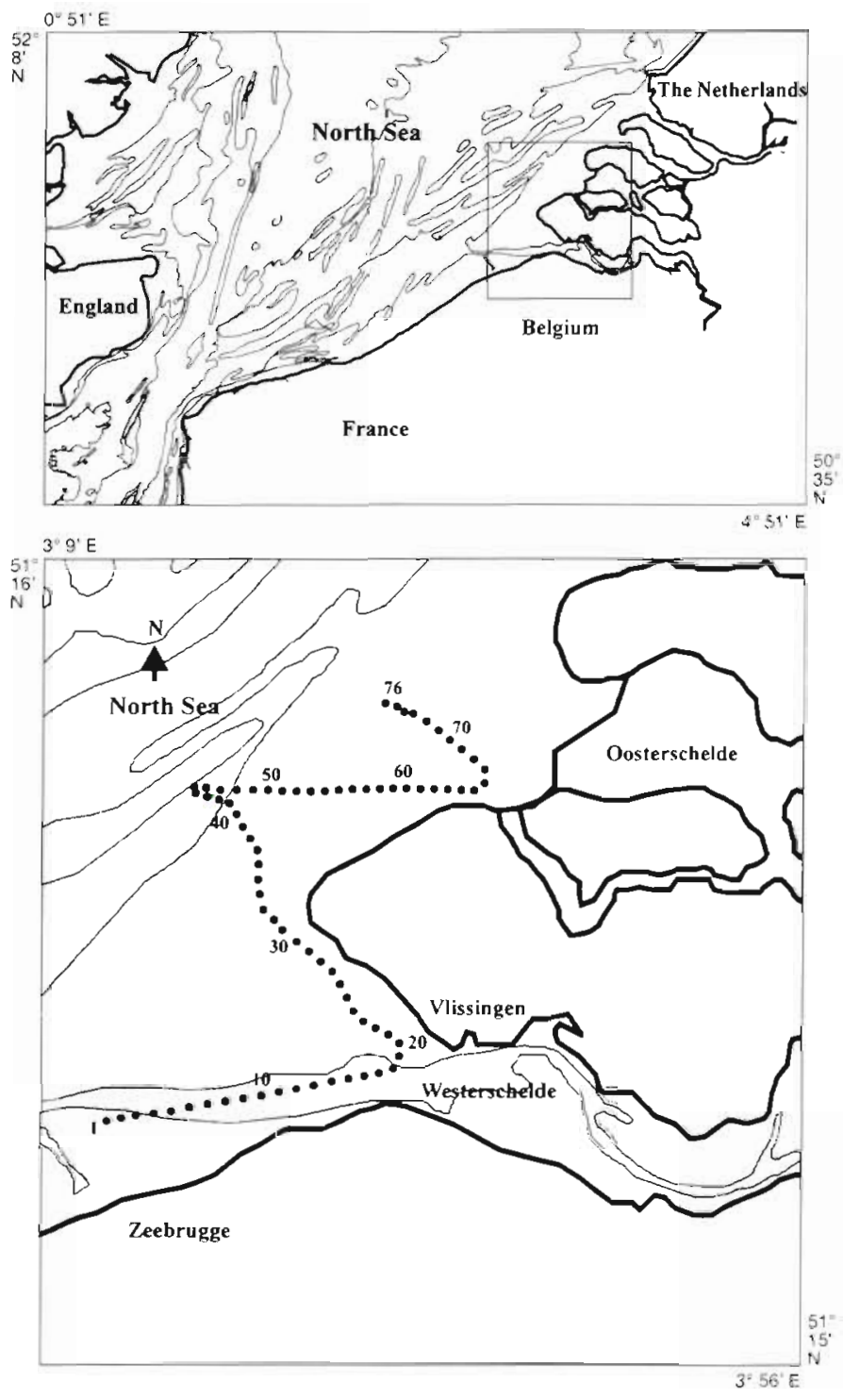

Fig. 1. Schematic map of the study area. The sampling transect along the coastline is represented by a dotted line
Table 1. Taxonomic groups and environmental variables

\begin{tabular}{|ll|}
\hline Taxonomic groups & Environmental variables \\
\hline Lanice conchilega & Salinity $(\mathrm{ppt})$ \\
Pectinaria koreni & Temperature $\left({ }^{\circ} \mathrm{C}\right)$ \\
Magelona mirabilis & Density $\left(\mathrm{kg} \mathrm{m}^{-3}\right)$ \\
Polydora spp. & Corrected depth $(\mathrm{m})$ \\
Nephtys spp. & Tidal height $(\mathrm{m})$ \\
Ampharetidae & Fluorometry $\left(\mathrm{chl} a \mu \mathrm{g} \mathrm{l}^{-1}\right)$ \\
Bivalves & \\
Echinoids & \\
Ophiuroids & \\
\hline
\end{tabular}

Depth and corrected depth were measured on board by the Color Echo Sounder system (model Raytheon V800). For meroplankton, 70 and 76 samples were collected during the 2 cruises at $3 \mathrm{~m}$ depth by a volumetric pump (PCM Moineau, $2001 \mathrm{~min}^{-1}$ ), and sorted according to Frontier $(1969,1972)$. Environmental variables measured and taxonomic groupings used are listed in Table 1.

Numerical analysis. The 3 matrix data sets were tested with a canonical correspondence analysis (CCA). The CCAs were performed following ter Braak (1988a), and the method proposed by Borcard et al. (1992). The p-values for each analysis were determined by a Monte Carlo permutation test. The spatial distance matrix was produced by a cubic trend surface regression based on the geographic coordinates of the sampling stations along the path of the boat (Borcard et al. 1992). The Mantel and partial Mantel tests were performed following the methods proposed by Mantel (1967), Smouse et al. (1986), Legendre \& Troussellier (1988) and Legendre \& Fortin (1989). The CANOCO program (ter Braak 1988b), and the R Package for Multivariate Data Analysis (Legendre \& Vaudor 1991) were also used in this study.

\section{RESULTS}

\section{Abiotic and biotic spatial variation}

The composite NOAA-AVHRR images from the end of May to mid June 1990 clearly show the major spatial differences in sea surface temperatures (Fig. 2A) and suspended matter distribution (Fig. 2B). Temperature values range from $15^{\circ} \mathrm{C}$ close to the coast to $13^{\circ} \mathrm{C}$ in the waters surrounding the Schelde estuarine system. The suspended matter distribution showed that the major inputs of nutrient-rich waters came from the Westerschelde. The first cruise on 5 June was carried out after a week of strong southwest winds with gusts up to $30 \mathrm{~m} \mathrm{~s}^{-1}$; during sampling the southwest wind velocity decreased to $7 \mathrm{~m} \mathrm{~s}^{-1}$. The second cruise on 11 June was 


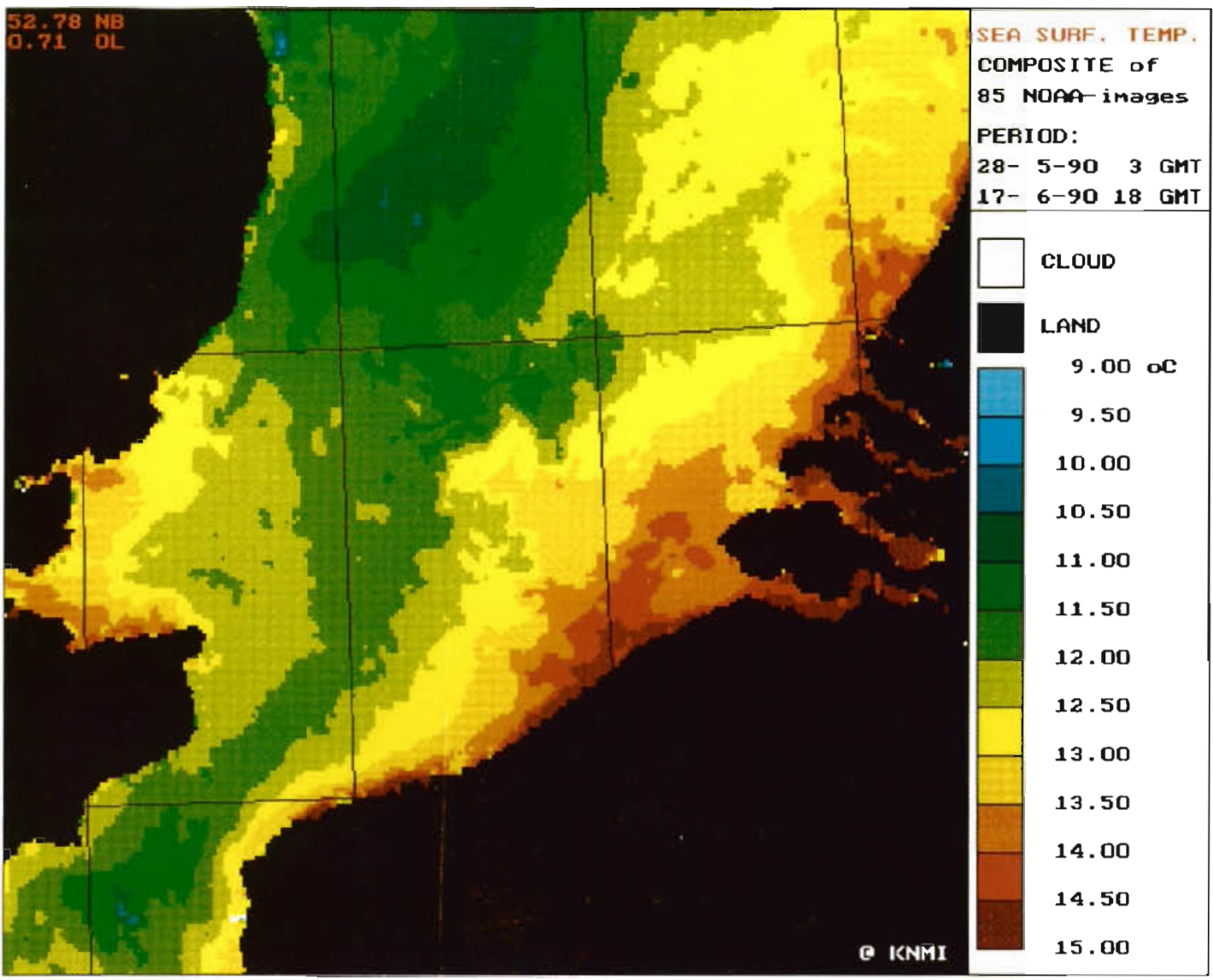

B

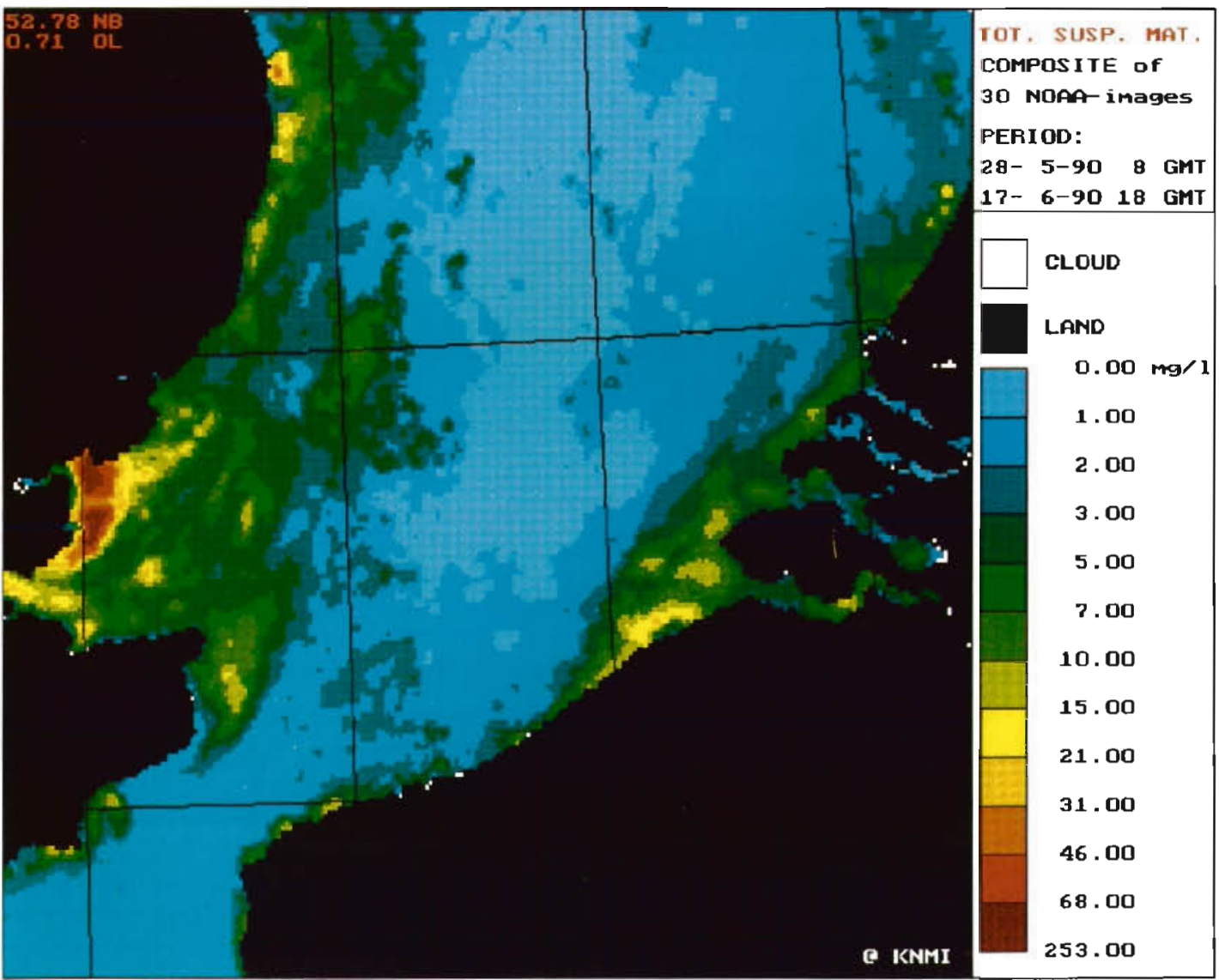

Fig. 2. NOOAA-AVHRR satellite composite images (KNMI 1990), showing (A) the sea surface temperature distribution and (B) the total suspended matter distribution for 28 May to 17 June 
subjected to a northeast wind with an estimated wind velocity of $5.5 \mathrm{~m} \mathrm{~s}^{-1}$. The temperature distribution for 5 June (Fig. 3A) showed the highest value of $16.3^{\circ} \mathrm{C}$ at $\operatorname{Stn} 20$ at the mouth of the Westerschelde, decreased towards the Oosterschelde, and reached the lowest value of $15.91^{\circ} \mathrm{C}$ at $\operatorname{Stn} 64$. During the second cruise the temperature distribution (Fig. 3B) clearly showed the input of warmer water coming from the Westerschelde, with the highest value of $16.29^{\circ} \mathrm{C}$ at Stn 21 . The salinity distribution for 5 June (Fig. 4A) showed that the highest salinity value of $32.73 \mathrm{ppt}$ was found at Stn 15 on the northern Belgian coast, and decreased towards the Westerschelde (Stn 20) and along the Dutch coast (Stns 30 to 40 ); the lowest salinity value of $32.47 \mathrm{ppt}$ was found in proximity to the Oosterschelde at Stn 55. For 11 June the salinity distribution (Fig. 4B) clearly showed the presence of the Westerschelde with the lowest value of $30.10 \mathrm{ppt}$ at Stn 21 . The highest salinity was found at Stn 41 along the Dutch coast, with a value of $32.95 \mathrm{ppt}$. The total suspended matter distribution, as a measure of chlorophyll a (chl a), showed on 5 June (Fig. 5A) the highest value of $20 \mathrm{chl} \mathrm{a} \mu \mathrm{g} \mathrm{l}^{-1}$ at Stns 22 and 28 at the mouth of the Westerschelde.

The fluorometry distribution decreased as we moved along the Dutch coast, reaching the

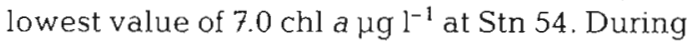
the second cruise, the fluorometry distribution (Fig. 4B) showed the input of nutrient-rich waters $\left(22.05 \mathrm{chl} \mathrm{a} \mu \mathrm{g} \mathrm{l}^{-1}\right)$ coming from the Westerschelde along the flood-tide channel running parallel to the Dutch coast from Stns 21 to 30. At the Oosterschelde (Stn 70), the fluorometry value was $17.2 \mathrm{chl} \mathrm{a} \mu \mathrm{g} \mathrm{l}^{-1}$. The distribution of the 3 environmental variables described here was subjected to a southwest wind during the first cruise, which enhanced mixing. During the second cruise, a light northeast wind condition caused less mixing to occur.

As an example of the spatial distribution of the taxonomic group, we present the distribution of the ophiuroid brittle star larvae along with temperature, salinity, and fluorometry distribution. The ophiuroid density distribution with temperature (Fig. 6A) showed the highest density value of 120 ind. $\mathrm{m}^{-3}$ at Stn 60 for the first cruise, concomitant with a temperature value of $16^{\circ} \mathrm{C}$. On 11 June (Fig. 6B), the ophiuroid density distribution showed 2 distinct input points between Stns 26 and 31 (500 ind. $\mathrm{m}^{-3}$ ) at the mouth of the western Scheldt, and
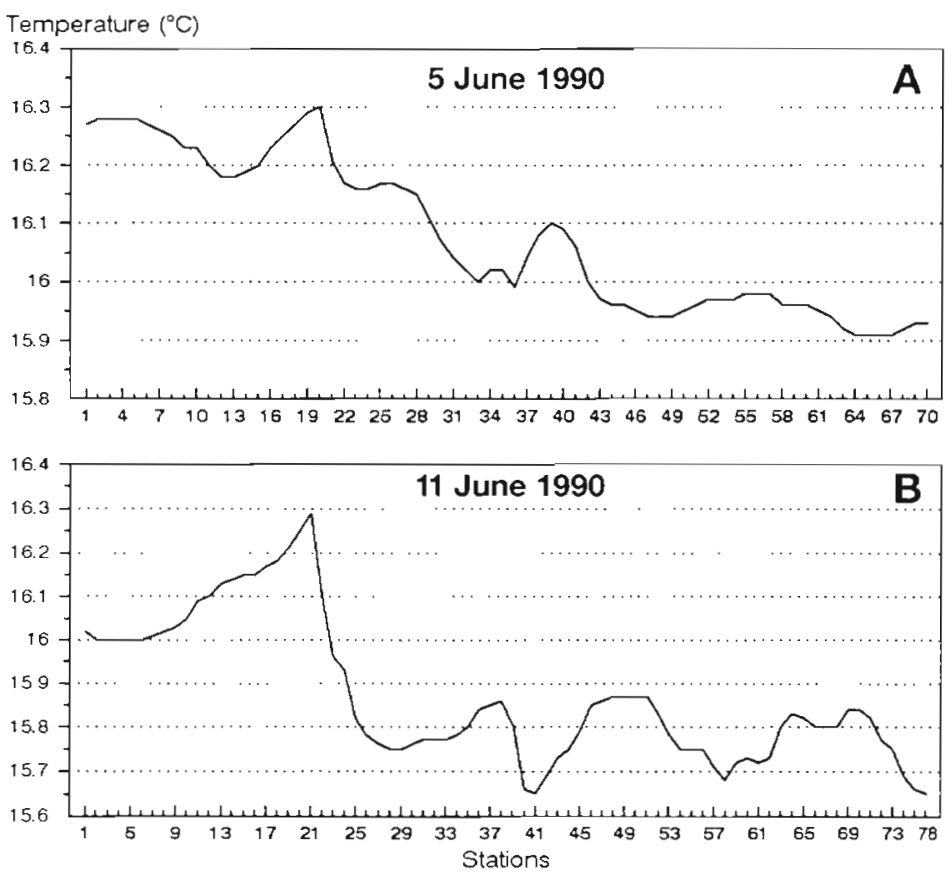

Fig. 3. (A) Temperature distribution for the first cruise, influenced by the southwest wind; $(B)$ temperature distribution for the second cruise, influenced by a light northeast wind
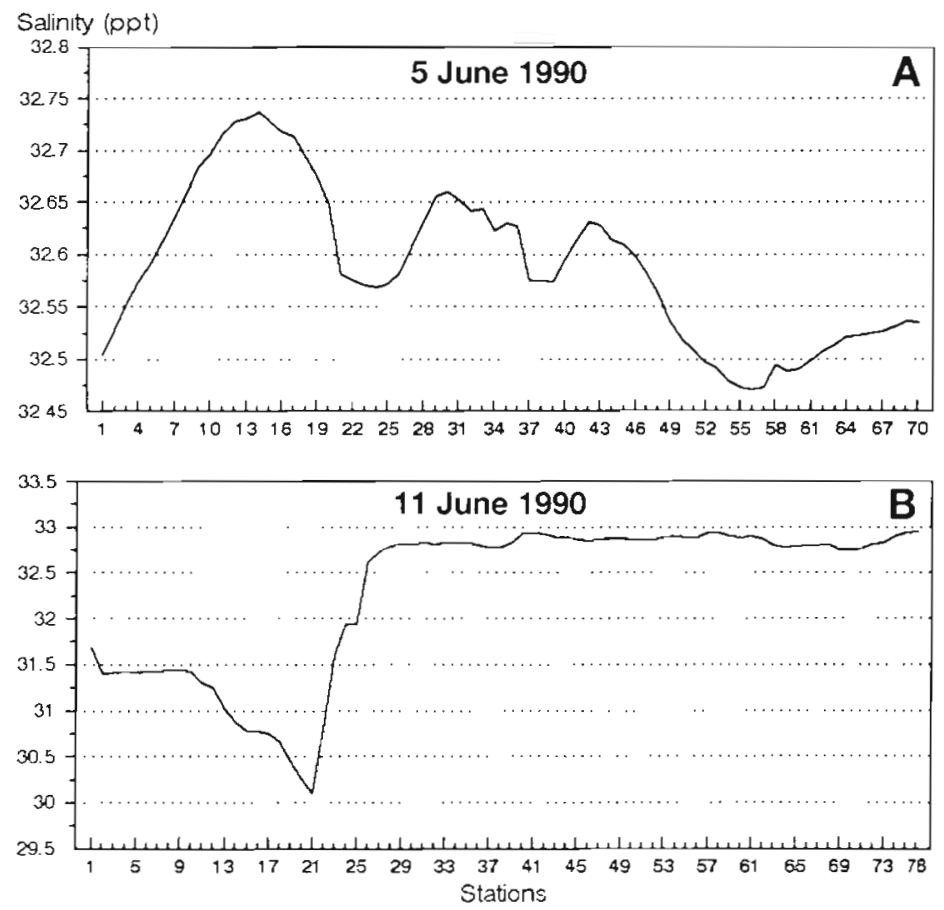

Fig. 4. (A) Salinity distribution for the first cruise, (B) salinity distribution for the second cruise showing the presence of Westerschelde water at Stn 21 
between Stns 64 and 76 (590 ind $\mathrm{m}^{-3}$ ), at the eastern Scheldt. For the first transect the highest density of ophiuroid was associated with a salinity value of $32.51 \mathrm{ppt}$ (Fig. 7A) at Stn 60; for the second cruise (Fig. 7B), the highest density was found at $\operatorname{Sin} 69$ at a salinity value of $32.92 \mathrm{ppt}$. When considering the ophiuroid distribution in respect to fluorometry, we found that for 5 June (Fig. 8A), the highest density values of ophiuroid were associated with a fluorometry of $18 \mathrm{chl}$ a $\mu \mathrm{g} \mathrm{l}^{-1}$ (Stn 22), at the western Scheldt, and at Stn 60 along the Dutch coast with a lower fluorometry value of $7.9 \mathrm{chl} \mathrm{a} \mu \mathrm{g} \mathrm{l}^{-1}$. For 11 June (Fig. 8B), the highest densities were found at Stn 28 along the flood-tide channel of the western Scheldt in proximity to Vlissingen, at

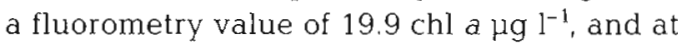
Stn 69 at the eastern Scheldt at a lower fluorometry value of $7.9 \mathrm{chl} \mathrm{a} \mu \mathrm{g} \mathrm{l}^{-1}$. The spatial distribution of the ophiuroid larvae suggested the existence of 2 distinct input points, at the 2 branches of the Scheldt estuary. During the first cruise the effect of the southwest wind enhanced northward transport of ophiuroid larvae and their dispersal over a larger area. During the second cruise, the lower wind velocity and the reversed direction limited the larval dispersion to more confined locations.

\section{Canonical correspondence analyses}

The CCAs for each cruise are presented in Table 2 . The percentage of the total variation of the species matrix was divided into 4 fractions. For the first cruise on 5 June (Fig. 9A), the whole variation of the species matrix was $66.3 \%$, and was explained by Fractions (a) $9.5 \%$, the nonspatial environmental variation: (b) $43.1 \%$, the spatially structured environmental variation, (c) $13.7 \%$, the spatial species variation not shared by the environmental variables; and (d) $33.7 \%$, the expression of the unexplained variation. For the second cruise on 21 June the results are reported in Fig. 9B. The Monte Carlo permutation test on the trace statistics for both sets of analyses was significant at a Bonferronicorrected $\alpha^{\prime}$ probability level of $0.05 / 4=$ 0.0125 . The effect of the southwest wind during the first cruise enhanced more mixing with the nutrient-rich waters coming from the Westerschelde. Fraction (c), representing the purely spatial variation, showed the im-
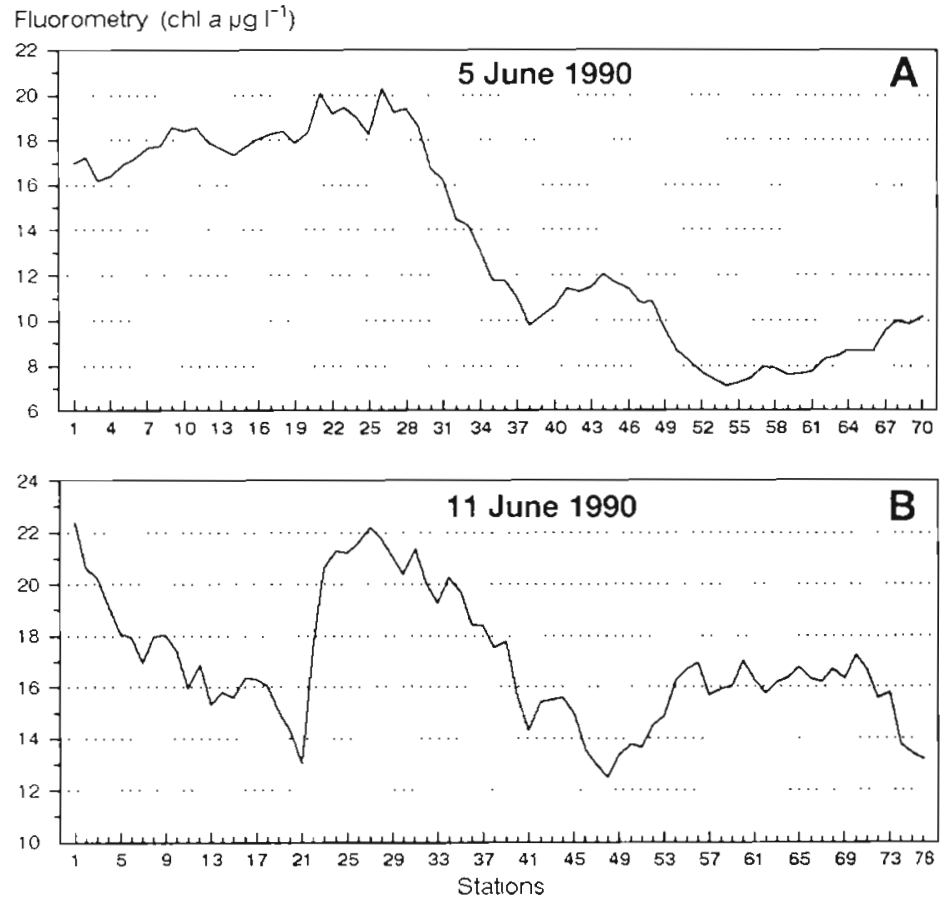

Fig. 5. (A) Fluorometry distribution for the first cruise, showing more mixing occurring due to the effects of the southwest wind; (B) fluorometry distribution for the second cruise, with light northeast wind conditions and the presence of nutrient-rich waters coming from the Westerschelde (Stns 22 to 33). Input from the Oosterschelde (Stns 61 to 76 ) is clearly detectable
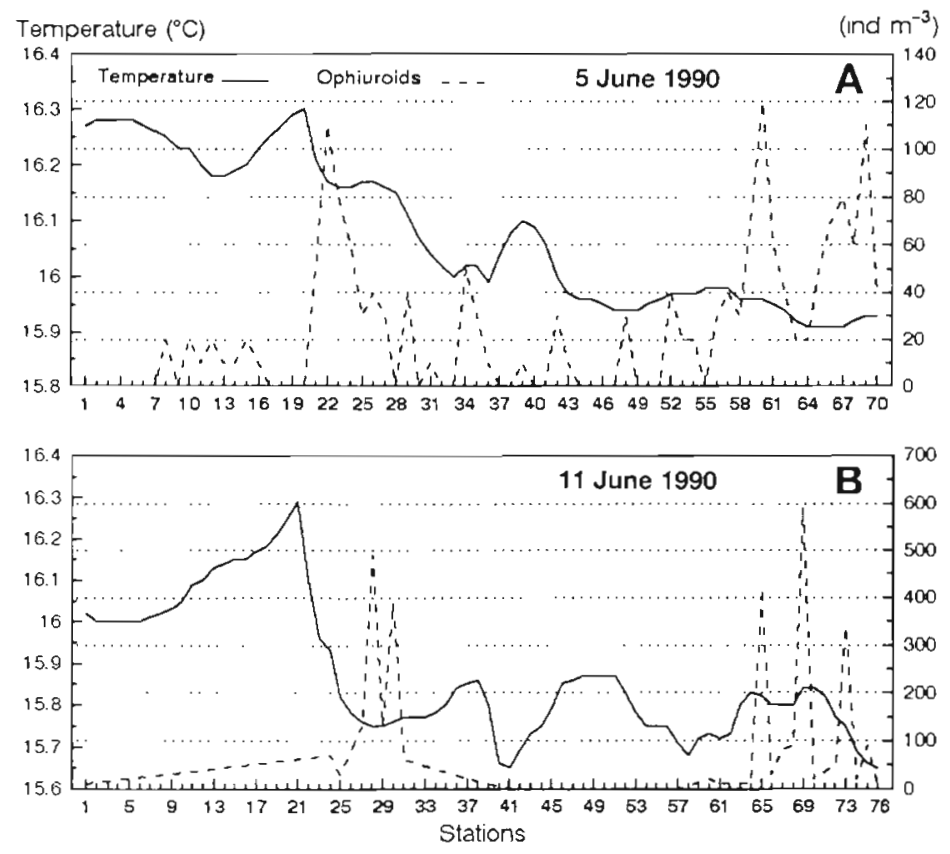

Fig. 6. Distribution of ophiuroid larvae with temperatures for (A) the first cruise, (B) the second cruise, showing 2 distinct populations 


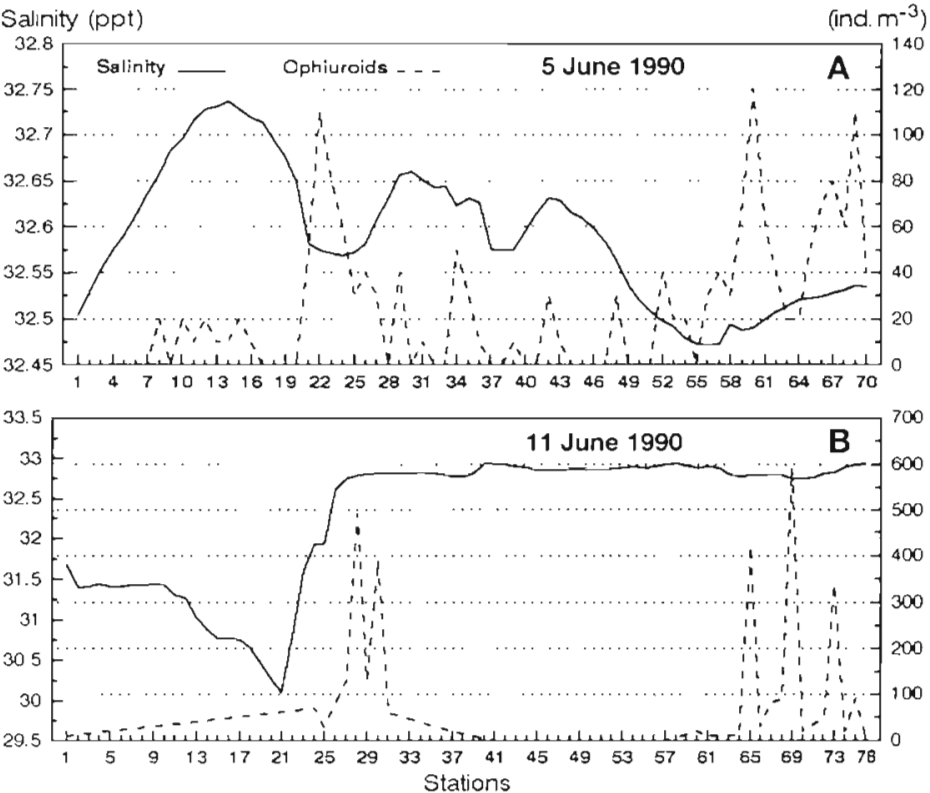

Fig. 7. Distribution of ophiuroid larvae with salinity for (A) the first cruise, $(B)$ the second cruise

portance of space as an explanatory variable. The unexplained variation, Fraction (d), would have been larger if the spatial structure was not included in the model. The use of more environmental variables is not necessarily a solution for explaining this fraction of the variability. The unexplained variation can partly represent the large amount of stochastic variation, and partially unmeasured factors and biotic processes, such as behavioural responses, whose spatial structures are still difficult to model (H. J. B. Birks pers. comm.). For the second cruise Fraction (b) was higher, confirming that the structure in the meroplankton distribution comes from the structuring of environmental variables. To be able to quantify the different fractions that explain the species variation and allow a better understanding of the variation between the spatial and environmental component and also to derive a general framework for the causal modelling of the various fractions partitioned it was necessary to perform the complimentary Mantel statistics (Borcard \& Legendre 1994).

\section{Mantel and partial Mantel tests}

The Mantel test among the 3 matrices considered (1) geographic distance, (2) environmental variables, and (3) species for the 2 sampling dates, with the following correlations:

$$
\begin{aligned}
\text { 5 June 1990: } & R_{1,2}=0.398(p<0.001) \\
& R_{1,3}=0.158(p<0.001) \\
& R_{2,3}=0.412(p<0.001) \\
11 \text { June 1990: } & R_{1,2}=0.425(p<0.001) \\
& R_{1,3}=0.181(p<0.001) \\
& R_{2,3}=0.449(p<0.001)
\end{aligned}
$$

For both sets of calculations the null hypothesis $\left(\mathrm{H}_{0}\right)$ that the multivariate data are not autocorrelated as a gradient was rejected at the $1 \%$ significance level according to the test of significance in Mantel statistics (Mantel 1967). The partial Mantel tests for the 2 campaigns gave the following correlations:

$$
\begin{array}{rll}
5 \text { June 1990: } & R_{1,2}=0.370(p<0.001)^{\circ} \\
& R_{1,3}=-0.007(p=0.65692) n s \\
& R_{2,3}=0.385(p<0.001)^{\circ} \\
11 \text { June 1990: } & R_{1,2}=0.391(p<0.001)^{\circ} \\
& R_{1,3}=-0.012(p=0.87456) n s \\
& R_{2,3}=0.417(p<0.001)^{\circ}
\end{array}
$$

The partial Mantel tests for the 2 transects show that the computed partial correlation between the geography (space) matrix and the species (meroplankton) matrix $\left(R_{1,3}\right)$ was non-significant (ns) The correlations between the geography (space) matrix and the environment $\left(R_{1,2}\right)$; and between the environment and the species (meroplankton, $R_{2,3}$ ) were highly significant ( $\left(^{*}\right)$ at a Bonferroni-corrected $\alpha$ probability level of $0.05 / 4=0.0125$. This result shows that the structure in the meroplankton distribution
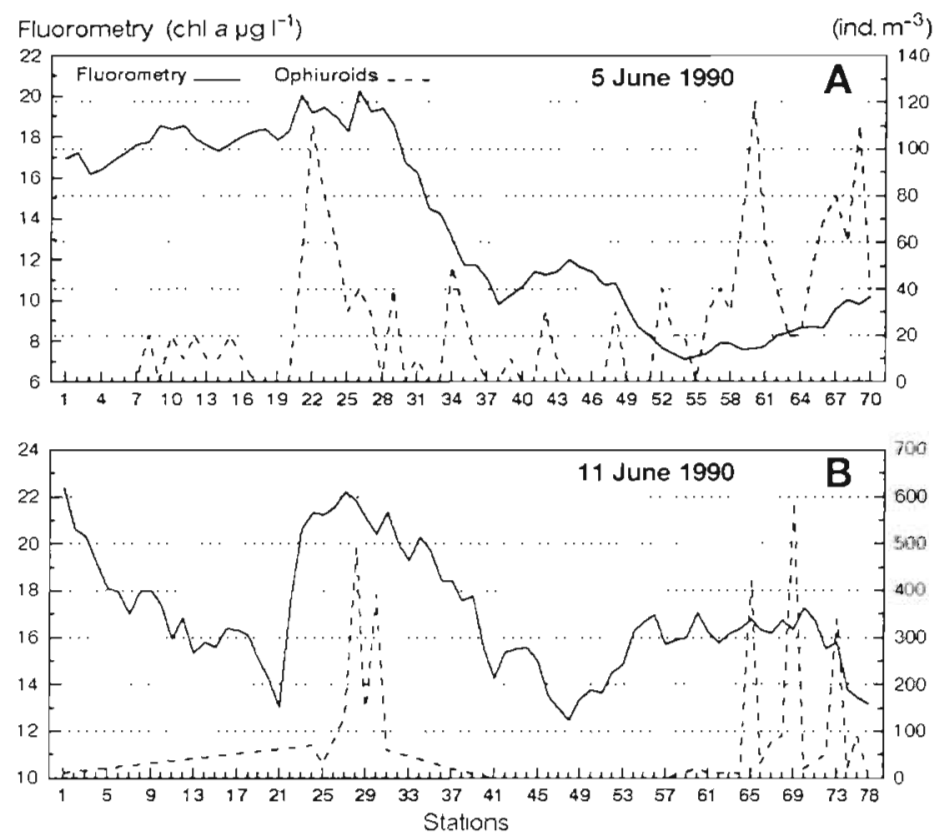

Fig. 8. Distribution of ophiuroid larvae with fluorometry for (A) the first cruise, (B) the second cruise 
Table 2. Results of the canonical correspondence analyses (CCA) are reported as the amount of canonical inertia explained by the SE (species-environment matrices), SS (species-space matrices), SE/S (species-environment matrices constrained by the space matrix), and SS/E (species-space matrices constrained by the environment matrix). Total inertia indicates the sum of all unconstrained eigenvalues. The overall amount of explained variation as a percentage of the total variation of the species-matrix for the 5 June 1990 was $66.3 \%$, obtained by summing Steps (1) \& (4), or Steps (2) \& (3), and partitioned as: (a) nonspatial environmental variation (Step 3): $9.5 \%$; (b) spatially structured environmental variation (Steps 1 to 3 , or Steps 2 to 4 ): $43.1 \%$; (c) spatial species variation not shared by environmental variables (Step 4): $13.7 \%$; (d) unexplained variation and stochastic fluctuations: $100-66.3=33.7 \%$. For 11 June 1990 the total explained variation was $69.5 \%$ and partitioned as: (a) $10.5 \%$, (b) $50.3 \%$, (c) $8.7 \%$, (d) $30.5 \%$

\begin{tabular}{|c|c|c|c|c|c|}
\hline Date & SE & SS & $\mathrm{SE} / \mathrm{S}$ & $\mathrm{SS} / \mathrm{E}$ & Total inertia \\
\hline 5 June 1990 & 0.149 & 0.161 & 0.027 & 0.039 & 0.283 \\
\hline 11 June 1990 & 0.621 & 0.602 & 0.105 & 0.089 & 1.02 \\
\hline \multicolumn{6}{|c|}{ Percentage of variation } \\
\hline \multirow{2}{*}{\multicolumn{3}{|c|}{$\begin{array}{c}\text { CCA } \\
5 \text { June } 1990\end{array}$}} & \multirow{2}{*}{\multicolumn{3}{|c|}{$\begin{array}{c}\text { CCA } \\
11 \text { June } 1990\end{array}$}} \\
\hline & & & & & \\
\hline \multicolumn{3}{|c|}{ Step (1): $0.149 \times 100 / 0.283=52.6 \%$} & \multicolumn{3}{|c|}{ Step $(1): 0.621 \times 100 / 1.02=60.8 \%$} \\
\hline \multicolumn{3}{|c|}{ Step (2): $0.161 \times 100 / 0.283=56.8 \%$} & \multicolumn{3}{|c|}{ Step (2): $0.602 \times 100 / 1.02=59 \%$} \\
\hline \multicolumn{3}{|c|}{ Step (3): $0.027 \times 100 / 0.283=9.5 \%$} & \multicolumn{3}{|c|}{ Step (3): $0.105 \times 100 / 1.02=10.5 \%$} \\
\hline \multicolumn{3}{|c|}{ Step (4): $0.039 \times 100 / 0.283=13.7 \%$} & \multicolumn{3}{|c|}{ Step (4): $0.089 \times 100 / 1.02=8.7 \%$} \\
\hline \multicolumn{3}{|c|}{ Total explained variation } & \multicolumn{3}{|c|}{ Total explained variation $=69.5 \%$} \\
\hline
\end{tabular}

ering the spatial component to describe the distribution of pelagic organisms. The innovative method of Borcard et al. (1992) quantified the percentage of the variation in the species matrix accounted for by the different fractions considered.

During the first cruise on 5 June, Fraction (c), representing the percentage of the variation in the species matrix due to the 'purely spatial' structure, was slightly higher than in the second cruise. This result suggested that in the coastal locations considered, the effect of strong southwest winds induces changes in the surface water distribution, and therefore, spatial structure plays an important role as a functional factor in the ecosystem. During the 11 June cruise the wind conditions were reversed, with a northeast wind and a very weak velocity. Under these circumstances the environmental structure was more evident, showing the presence of the 2 branches of the comes from the structuring of the environmental variables. The Mantel statistic describing the influence of the environment on the meroplankton community structure for 5 June is reduced from 0.412 to 0.385 when controlling for the effect of space. The specific influence of the environment is therefore 0.385, while the difference of $0.163(0.398 \times 0.412=0.163)$ can be regarded as the influence of the spatial structure imbedded in the environment on the species distribution. For 11 June, the Mantel statistic describing the influence of the environment on meroplankton was reduced from 0.449 to 0.417 when controlling for the effect of space. The influence of the environment of 0.417 , and the difference of $0.190(0.425 \times 0.449=$ 0.190 ), correspond to the influence on the species distribution exerted by the spatial structure present in the environment.

\section{DISCUSSION AND CONCLUSION}

As stated by Gould (1970), 'all our efforts to understand spatial pattern, structure, and process have indicated that it is precisely the lack of independence, the interdependence of spatial phenomena that allows us to substitute pattern, and therefore predictability and order, for the chaos and apparent lack of interdependence of things in time and space'. The results obtained in this study show the importance of consid-
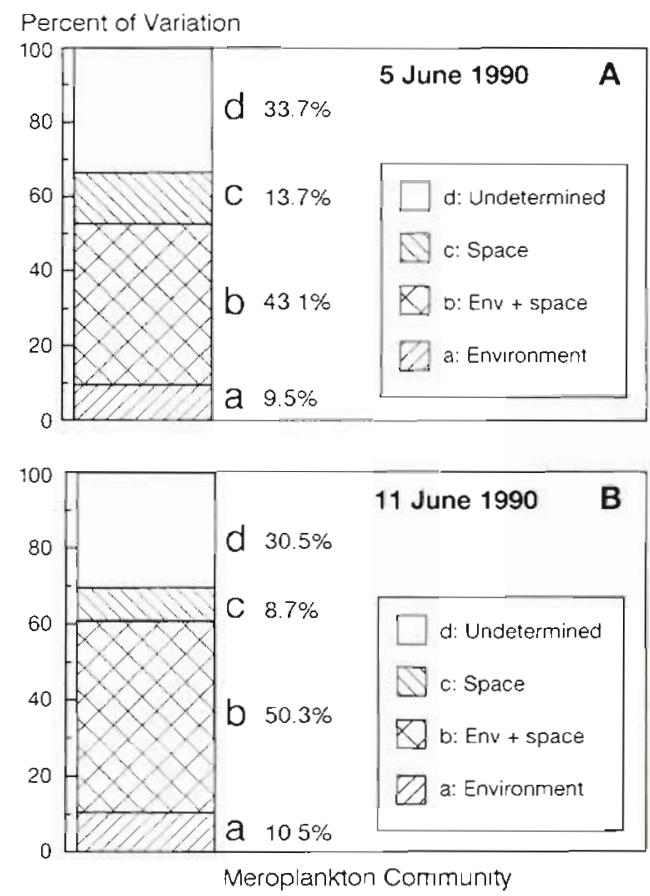

Fig. 9. (A) Variation partitioning of the meroplankton community data matrix for the first cruise. The whole variation of the species matrix is partitioned into 4 fractions: (a) nonspatial environmental, (b) spatially structured environmental variation, (c) spatial species variation not shared by the environmental variable, (d) undetermined variation and stochastic fluctuations. (B) Variation partitioning of the meroplankton community data matrix for the second cruise 
Schelde clearly defined by the spatial distribution of abiotic variables. Fraction (b), representing the percentage of variation in the species matrix due to environment and space, was higher than in the first cruise, suggesting that with less wind forcing the surface water and less mixing, the spatial changes in the environmental variables more clearly explained the variation observed at the species level. The use of more environmental variables in the CCA allowed for the performance of a multiple linear least-squares regression with the weighted averages of the species as dependent variables and the environmental variables as independent variables (Palmer 1993). The use of covariables as suggested by ter Braak (1988a) as partial ordination allowed the partialling of the environmental and spatial variations, and the linkage of these factors to the species data (Legendre 1990).

The results obtained from the Mantel tests clarified, as suggested by Legendre \& Troussellier (1988), the relations between the factors influencing the environmental variables and the influence of the environment on species distribution. The spatial fraction of the variation can be used as an explanatory variable when the environmental factors considered are not sufficient to explain the remaining spatial variation. The use of spatial terms in the data analysis allowed us to explain the spatial variation of the species composition and to segregate the deterministic components of the unexplained variation, Fraction (d), to a local area within the sampling locations (Borcard et al. 1992). CCA and the complementary Mantel statistics can be used as exploratory techniques to investigate homogeneous ecological communities. The partial Mantel tests appeared to be quite powerful in bringing out dependence patterns between linked biological communities and their environments.

The spatial structure in the species data considered in this work came from a spatial structuring of the environmental variables with reference to the environmental control model (ECM) (Whittaker 1956, Borcard \& Legendre 1994). The partial ordination technique allowed selection of the environmental and spatial factors that can explain variations in species composition. The use of covariables in CCA and tests for statistical significance such as the Monte Carlo permutation test further extended the validity of using this method in direct gradient analysis (ter Braak \& Prentice 1988, Birks \& Austin 1992).

It is important to include spatial structure in ecological studies because it highlights the importance of the spatial variation, Fraction (c), in the species composition and can therefore be considered as a predictive variable. Legendre \& Troussellier (1993) showed that spatial structuring played an important role in a water circulation model to predict the spatial variations of the abundance of phytoplankton and heterotrophic bacteria in a brackish lagoon and to reduce the amount of unexplained variation. As stated by Mackas (1984), 'closely spaced or continuous samples are needed to resolve the detailed pattern of spatial variability; significant fractions of the total variance would be unresolved by conventional point sampling and would contribute to an inflated estimate of the residual statistical noise'. The coastal system studied in respect to the meroplankton community can be regarded as a complex biological flux system governed by wind conditions that can alter the transport and dispersion of larvae in a southwest-northeast gradient (Luczack et al. 1993). The meroplankton distribution pattern may correspond partly to the structuring of measured environmental variables, which in turn are themselves spatially structured, or to the fact that the stretch of coastline studied is itself a structuring factor. Turning the discussion to the ecologist, we may conclude from this work that partitioning the variation of the meroplankton community structure gives support to preconceived models of larval dispersion. Most importantly it suggests the need to go back to sampling with better models in mind. The method described can be a useful approach to the interpretation of the dynamics of marine ecosystems

Acknowledgements. This study is part of the RENORA project (Recrutement en mer du Nord dans le peuplement à Abra alba), founded by the PNDR (Programme National sur le Déterminisme du Recrutement France). Many thanks to Dr Hans Roozekrans at KNMI (Royal Netherlands Meteorological Institute) for providing the satellite images, to all the coworkers of P.L.'s laboratory in Montreal, and to H. J. B. Birks for a useful discussion. The authors are grateful to the reviewers for their helpful remarks on the initial manuscript.

\section{LITERATURE CITED}

Birks HJB, Austin HA (1992) An annotated bibliography of canonical correspondence analysis and related constrained ordination methods 1986-1991. Botanical Institute, University of Bergen, Norway, p 1-29

Borcard D, Legendre P (1994) Environmental control and spatial structure in ecological communities: an example using Oribatid mites (Acari, Oribatei). Environ ecol Stat 1.37-53

Borcard D, Legendre P, Drapeau P (1992) Partialling out the spatial component of ecological variation. Ecology 73(3): $1045-1055$

Dronkers J, Zimmerman JTF (1982) Some principles of mixing in tidal lagoons with examples of tidal basins in the Netherlands. Oceanol Acta 3:107-117

Frontier S (1969) Sur une méthode d'analyse faunistique rapide du zooplancton. J exp mar Biol Ecol 3:18-26

Frontier S (1972) Calcul de l'erruer sur un comptage de zooplancton. J exp mar Biol Ecol 8:121-132

Gould PR (1970) Is Statistix inferens the geographical name for a wild goose? Econ Geogr 46:439-448

Leewis RJ, Waardenburg HW (1990) Flora and fauna of the sublittoral hard substrata in the Oosterschelde (The 
Netherlands). Interactions with the North Sea and the influence of the storm surge barrier Hydrobiologia 195: $189-200$

Legendre P (1990) Quantitative methods and biogeographic analysis. In: Garbary DJ, South RR (eds) Evolutionary biogeography of the marine algae of the north Atlantic. NATO ASI Series, Vol G22. Springer-Verlag, Berlin, p 9-34

Legendre P, Fortin MJ (1989) Spatial pattern and ecological analysis. Vegetatio 80:107-138

Legendre P, Troussellier M (1988) Aquatic heterotrophic bacteria: modeling in the presence of spatial autocorrelation Limnol Oceanogr 33:1055-1067

Legendre P, Troussellier M (1993) Origin of spatial structures in aquatic bacterial communities: from hypothesis to numerical solutions. In: Guerrero R, Pedrós-Alió C (eds) Trends in microbial ecology. Proc 6th Intern Symp Microbial Ecology (ISME-6), Barcelona, 6-11 September 1992. Spanish Society for Microbiology, Barcelona, $p$ $353-358$

Legendre P, Troussellier M, Jarry V, Fortin MJ (1989) Design for simultaneous sampling of ecological variables: from concepts to numerical solutions. Oikos 55:30-42

Legendre P, Vaudor A (1991) The R Package: multidimensional analysis, spatial analysis. Département de sciences biologiques, Université de Montreal, p 147

Luczak C, Dewarumez JM, Essink K (1993) First record of the American jack knife clam Ensis directus on the French coast of the North Sea. J mar biol Ass UK 73:233-235

Mackas DL (1984) Spatial autocorrelation of plankton community composition in a continental shelf ecosystem. Limnol Oceanogr 29(3):451-471

Mantel N (1967) The detection of disease clustering and a generalized regression approach. Cancer Res 27:209-220

May RM (1984) An overview: real and apparent patterns in community structure. In: Strong DR, Simberloff D, Abele L, Thistel AB (eds) Ecological communities: conceptual issues and the evidence. Princeton University Press, Princeton, p 3-16

Nihoul JCJ (1975) Modeling of marine systems. In: Nihoul

This article was submitted to the editor
JCJ (ed) Elsevier Oceanography Series 10. Elsevier, Amsterdam, p 16-21

Nihoul JCJ (1980) Residual circulation, long waves and mesoscale eddies in the North Sea. Oceanol Acta 3: 309-316

Nihoul JCJ, Djenidi S, Hecq JH (1989) Modelling coastal shelf systems with emphasis on long term trends. Int J Num Meth Engineer 27:113-127

Nihoul JCJ, Ronday FC (1975) The influence of the 'tidal stress' on the residual circulation: application to the Southern Bight of the North Sea. Tellus 27:484-489

Nihoul JCJ, Runfala Y (1981) The residual circulation in the North Sea. In: Nihoul JCJ (ed) Ecohydrodynamics. Elsevier, Amsterdam, p 219-271

Palmer MW (1993) Putting things in even better order: the advantage of canonical correspondence analysis. Ecology $74(8): 2215-2230$

Smouse PE, Long CJ, Sokal RR (1986) Multiple regression and correlations extensions of the Mantel test of matrix correspondence. Syst Zool 35:627-632

ter Braak CJF (1987) Ordination. In: Jongman RHG, ter Braak CJF, van Tongeren OFR (eds) Data analysis in community and landscape ecology, Chap 5. PUDOC, Wageningen, p $91-173$

ter Braak C.JF (1988a) Partial canonical correspondence analysis. In: Block $\mathrm{HH}$ (ed) Classification and related methods of data analysis. North Holland Press, Amsterdam, p 551-558

ter Braak CJF (1988b) CANOCO - an extention of DECORANA to analyse species-environment relationships. Vegetatio 75:159-160

ter Braak CJF, Prentice IC (1988) A theory of gradient analysis. Adv ecol Res 18:271-313

Wetsteyn LP, Peeters JCH, Duin RNM, Vegter P, de Visscher RM (1990) Phytoplankton primary production and nutrients in the Oosterschelde (The Netherlands) during the prebarrier period 1980-1984. Hydrobiologia 195:163-177

Whittaker RH (1956) Vegetation of the Great Smoky Mountains. Ecol Monogr 26:1-80

Manuscript first received: January 20,1995

Revised version accepted: June 6, 1995 